\title{
CONTINUOUS IMPROVEMENT IN JUST IN TIME MANUFACTURING (JIT), A SYSTEMATIC LITERATURE REVIEW
}

\author{
Kruthi Chikkaballapur Balaji, Poorvika Gopal \\ Researchers, Department of Industrial Engineering and Management, JSS campus, JSS Academy of \\ Technical Education, Uttarahalli-Kengeri Road, Bangalore - 560060, Affiliated to Visvesvaraya \\ Technological University, Belagavi, Karnataka, \\ India \\ Dr. Rashmi S \\ Assistant Professor Department of Industrial Engineering and Management, JSS campus, JSS Academy \\ of Technical Education, Uttarahalli-Kengeri Road, Bangalore - 560060, Karnataka, India
}

\begin{abstract}
-
Objective: The study's initial goal is to become acquainted with the general Kaizen approach and the elements required for its successful implementation.

Methodology: It is critical to understand the success implementation factors to increase productivity and achieve value for the research that has been conducted in many manufacturing sectors. A systematic literature review (SLR) is conducted to gain a clear understanding of the various literature available in the search results for Continuous Improvements (CI) in Just-in-Time Manufacturing (JIT). To perform the SRL, 87 articles are accumulated from Google Scholar and screened according to the inclusion and exclusion criteria. Another 30 papers have been accepted, with the majority of them focusing on two research areas, namely continuous improvement in the automobile industry and successful implementation metrics. The 30 papers preferred are visualized based on the market, country of origin, variables, and approaches used by the multiple writers.
\end{abstract}

Conclusion: After conducting a thorough literature survey, it was evident that most authors pointed out the necessity of excellent communication channels, training, and education for successful CI adoption in the industries. All the researchers investigated change, employee and team preparation, and commitment to change. One study advocated innovatively using change management tools.
Keywords: JIT, Continuous Improvements, systematic review, Success factors, Kaizen, Manufacturing

\section{INTRODUCTION}

In the dynamic competitive market, which has highly fluctuating needs and demands organizations must be flexible enough to respond to the swings, just in time. A just-in-time approach prevents excessive production, which occurs when the supply of a product in the market outnumbers demand, resulting in an accumulation of unsold goods, and also helps in coping with an increase in demand for the same product. The JIT production process, which operates on a demand-pull basis, is completely under the control of the manufacturer, hence avoiding any sorts of losses. Kaizen or continuous improvement is one of the elements of JIT, the best thing about Kaizen is that it never ends, and there is always room for improvement. This provides a large number of opportunities for the company to improve. Hence, it's critical to understand the research and former Kaizen applications in organizations to gain a sense of how to adapt it to current demands.

\section{Genesis of JIT}

JIT is a Japanese style of management that has been used in many Japanese industrial organizations since the early 1970s. Taiichi Ohno pioneered and honed it inside Toyota manufacturing operations to address consumer requests with minimal delays. Taiichi Ohno is widely regarded as the "Father of JIT."

The 1973 OPEC (Organization of the Petroleum Exporting Countries) driven oil crisis increased 


\section{International Journal of Engineering Applied Sciences and Technology, 2021 Vol. 6, Issue 2, ISSN No. 2455-2143, Pages 77-94 \\ Published Online June 2021 in IJEAST (http://www.ijeast.com)}

industrial costs, produced balance-of-payments issues for all developed nations, and resulted in recession. The Westerners pursued national socioeconomic and political answers while grappling with the rising wages at the corporate level. Likewise, the Japanese were adopting factory management systems that allowed them to function with very low inventories due to a scarcity of natural resources, limited space, and insufficient overseas investors.

Toyota was able to confront the mounting problems of survival by focusing on people, plants, and systems. Toyota acknowledged that JIT would only be effective if every employee in the organization was involved and dedicated to it, if the factory and techniques were set designed for maximum productivity and quality, and if quality and production schedules were precisely timed to meet demand.

What is Just in Time?

Just in Time is a form of managing inventory in which commodities are only obtained from providers, when necessary. This strategy aims mainly to lower the holding costs of inventories and to promote inventory sales. It is only in time that the complete supply chain must be meticulously planned and the use of better software must be carried out to carry out the whole process till it is delivered. The objective of a JIT firm is to supply its clients with items without any inventory and at no cost after no lead time.

JIT is defined as "JIT is creating a flexible atmosphere in which everyone works to remove waste and to simplify processes so that total business performance is continuously improved." (Lea \& Parker, 1989) ${ }^{[1]}$. And about basic elements of Just-in-time, back in the 1950s, Japan focused on increased performance by paying special attention to lowering the amount of money and space available. The Toyota Chairman, Eiji Toyota, gave his workers a directive "to remove the waste," established the groundwork for developments in JIT. Waste was described as "anything else that is indispensable for adding value to the product than minimal amounts of equipment, materials, parts, space and time." Hence, the manufacturing process of JIT is the outcome of the waste disposal requirement. The following elements are the results of the developments led by Eiji Toyota: flexible resources, cellular layout, pull production system, continuous improvement, kanban production control, small-lot production, quick setups, quality at the source, total productive maintenance, uniform production levels supplier networks, etc., Given that our focus is mainly on continuous improvement, we would want to brief you more about the continuous improvements in just in time.
Continuous Improvement

Continuous improvement (CI) is a strategy Deming has stated as simply "increasing successful efforts and reducing failures". Kaizen has been characterized by different writers, including Audretsch et al, Imai, and others. According to author Audretsch et al., it is a systematic approach to management aimed at continuous performance improvement through a progressive process of everlasting change. It is described by Berling (2000) ${ }^{[2]}$ as one of the activities that execute processes and procedures that contribute to organizational objectives by utilizing a $\mathrm{CI}$ in work processes, workspaces, and work interaction. It was described by Imai, as a method of constant improvement in personal life, family life, social life, and job life. Kaizen in the workplace refers to continuous improvement that involves both management and employees. Brooks also stated in 1993 that "change for the better" will occur. A further definition of $\mathrm{CI}$ is the "targeted and ongoing progressive innovation process" ${ }^{[3]}$. "A systemic approach to management aimed at continuous improvement of performance through a progressive process of unending change" (Audretsch et al., 2011)

[4]. Continuous improvements are considered as "one of the activities that execute processes and procedures that contribute to organizing objectives by employing a CI in work processes, workplaces, content and work interaction."(Berling, 2000) ${ }^{[2]}$. CI is known also as a Kaizen using Japanese terminology (Hayes, 1981) ${ }^{[5]}$. CI assists improvements through the provision of a range of more complex tools and approaches to identify and minimize sources of inconsistency, waste, and other reduction problems. CI quite broadly as a culture of persistent improvement aimed at eliminating waste throughout an organization's systems and activities. It entails everybody working together to develop without having to spend heavily on cash. In this situation, improvement can occur via evolutionary improvement or drastic changes due to an inventive concept or new technology.

The aforementioned versions of the CI highlight several comprehensive, long-term commitments towards developing the company with the common necessity to understand client expectations. Note that since the 1980s, quality management has been working towards integrating and emphasizing customer demands as part of the change from a focus on internal efficiency and product-related procedures (Gronroos, 2007) ${ }^{[6]}$. Bhuiyan and Baghel (2005) ${ }^{[7]}$ proclaim that efforts for continuous improvement seek, through integrating all engaged, to develop a culture of continuous improvement. Typically, these improvements are progressive and there are overall more important outcomes from the accumulation of 


\section{International Journal of Engineering Applied Sciences and Technology, 2021 \\ Vol. 6, Issue 2, ISSN No. 2455-2143, Pages 77-94 \\ Published Online June 2021 in IJEAST (http://www.ijeast.com)}

comprehension of how each criterion may affect the experiment's accuracy (Patino and Ferreira, 2018) ${ }^{[9]}$. Inclusion requirements are everything that a thesis needs to present to be included in a review's examination. The exclusion criteria are the elements that would make a study ineligible for inclusion in your review. Dates, how a study was designed, population, outcomes, and so on are examples of these needs. This creation of inclusion and exclusion criteria occurred in two stages: domain criteria and language criteria. The first inclusion criterion excludes published documents, papers, or articles that have not yet been published in journals. The domain is the subsequent criterion that identifies the research's area of emphasis. The articles classified as 'Continuous Improvement' are included in this case. The third criterion is the manuscript's language; any language other than English is ruled out of the study

Table 1: Inclusion and Exclusion Criteria

\begin{tabular}{|c|c|c|}
\hline Criteria & Inclusion & Exclusion \\
\hline Document Type & Published documents & $\begin{array}{c}\text { Ongoing, Unpublished, into from or } \\
\text { upcoming documents. }\end{array}$ \\
\hline Domain & $\begin{array}{c}\text { Continuous Improvement } \\
\text { In JIT }\end{array}$ & Other elements of JIT \\
\hline Language & English & Other than English \\
\hline
\end{tabular}

\section{DATABASE AND SEARCH STRATEGIES}

A total of "30" previously published papers are chosen and retrieved from the internet. 10 articles discussed the notion of continuous improvement, 10 papers dealt with continuous improvement, and another 10 dealt with success factor implementation. Specific search phrases and search strings are given to Google Scholar to locate the documents. Following a review of the paper suggested by the Google Scholar results, the references of that document are checked to see if there are any further publications to review.

\section{Search terms}

Just-in-time, Continuous Improvement, Systematic review, Kaizen, Toyota production systems, Elements of JIT, Implementation, Manufacturing, Performance Measurement, success factors are the terms and keywords used to search articles.

\section{Search strings}

The following search strings are used to find research papers on Google Scholar:
"Just-in-time" and "Manufacturing"

"Just-in-time" and "Kaizen"

"Just-in-time" and "Implementation"

"Toyota production systems" and "Elements of JIT"

"Toyota production systems" and "Kaizen"

"Continuous Improvement" and "Performance Measurement"

"Systematic review" and "JIT"

"Continuous Improvement" and "Success Factors"

"Performance Measurement" and Success Factors"

"Manufacturing" and "JIT implementation"

"Kaizen implementation" and "Performance Measurement"

Document selection 
The papers available for download are divided into two categories: continuous improvement in the automobile sector and continuous improvement effective implementation factors. Papers concentrating on other aspects of JIT, on the other hand, are omitted from the study. Initially, 87 papers on continuous improvement are retrieved, 10 of the 19 screened papers on overview of CI whereas, 10 of the 13 screened CI Successful implementation criteria are obtained. 10 of the 16 screened automobile papers are accepted. The reasons for the remaining 57 publications not being checked and accepted could be:

(i) a lack of accessibility of specific data used by the authors, such as variables, methodologies, or statistical analysis,

(ii) other than JIT manufacturing.

Table 2: Document Selection

\begin{tabular}{|c|c|c|c|}
\hline Sectors & Initial & Screened & Accepted \\
\hline An overview of CI & 31 & 19 & 10 \\
\hline CI in the automotive sector & 27 & 16 & 10 \\
\hline CI Successful implementation factor & 29 & 13 & 10 \\
\hline Total & & & 30 \\
\hline
\end{tabular}

\section{IDENTIFICATION OF SUCCESS FACTORS}

Initially, a detailed examination of Continuous improvement and $\mathrm{CI}$ in the automotive industry was conducted to discover the success elements for adoption. This section provides an overview of CI, its evolution, and the key parameters for its implementation.

\section{Review on CI:}

Barara et al. (2011) ${ }^{[10]}$ conducted a study that looked at the many definitions of Kaizen in the academic literature and then looked at Kaizen research. They look for common ground or potential guiding principles and/or cornerstones in what they refer to as 'Kaizen.' Kaizen is a Japanese word that refers to how people deal with challenges daily. Some regard it as a method to reconcile his values with the values of his environment. As a result, kaizen can be viewed as a principle of "individual spirit" of collaboration and improvement

The Japanese version of Kaizen is almost non-existent, although it is readily applied in other nations. It may take at least three forms: employee-driven improvement efforts, inter-departmental and functional communication, employee discipline, and job standardization to reduce "Muda." Aoki (2008) [11] finds that it is possible to transfer Kaizen to other nations with distinct cultures than Japan, provided that these organizations are successfully implemented outside of Japan. Senior management is responsible for innovation and improvement, while intermediate managers and employees are responsible for maintaining work standards and guaranteeing incremental improvements. The word most often used 
in the literature with regard to the Western version of Kaizen is CI, but as some authors point out, it is more frequently used in relation to the Japanese variant.

The Western version of Kaizen is not a fixed idea, but rather one that has evolved through five stages (preCI, structured, goal-oriented, proactive, CI capability) The most recent development in the World literature on Kaizen is the possibility of a link between the word and the Lean-Six Sigma methodology. The present research of management theories and teachings on CI as the basis of Kaizen supports a Western worldview, implying that Kaizen is simply "the Japanese CI." The dominance of CI may be explained in part by the fact that English is a more prevalent language in academic settings than Japanese (Carnerud et al., 2018) ${ }^{[12]}$. 
International Journal of Engineering Applied Sciences and Technology, 2021

Vol. 6, Issue 2, ISSN No. 2455-2143, Pages 77-94

Published Online June 2021 in IJEAST (http://www.ijeast.com)

Table 3: Summary of CI review

\begin{tabular}{|c|c|c|c|c|}
\hline Sl no & Authors & Purpose & Practical Approach & Key Research Findings \\
\hline 1 & $\begin{array}{l}\text { Barazza et al., (2011) } \\
\text { [13] }\end{array}$ & $\begin{array}{l}\text { To examine Kaizen in academic and } \\
\text { practitioner literature to gain a better } \\
\text { understanding of it and to contribute to its } \\
\text { theoretical profile. }\end{array}$ & $\begin{array}{l}\text { Kaizen was used as a search phrase in a literature review. For } \\
\text { this, a variety of databases were used, as well as publications } \\
\text { produced by both academics and practitioners on the subject. } \\
\text { The literature on Kaizen was systematically analyzed and } \\
\text { classified. }\end{array}$ & $\begin{array}{l}\text { According to the study's findings, Kaizen is currently represented by } \\
\text { three perspectives or umbrellas, each of which includes a set of concepts } \\
\text { and procedures. When the three viewpoints are compared, kaizen } \\
\text { emerges as a management principle, a component of Total Quality } \\
\text { Management, and a philosophy for continuous development. }\end{array}$ \\
\hline 2 & $\begin{array}{l}\text { Carnerud } \\
(2018)^{[12]}\end{array}$ et al., & $\begin{array}{l}\text { To show how Kaizen and continuous } \\
\text { improvement }(\mathrm{CI}) \text { have been illustrated in } \\
\text { quality management (QM) publications } \\
\text { since the } 1980 \text { s. This study will examine } \\
\text { how Kaizen is described, as well as how it } \\
\text { is pictured concerning CI. }\end{array}$ & $\begin{array}{l}\text { Using mixed-methods research, the study looks for Kaizen } \\
\text { and CI patterns and themes in four scientific publications that } \\
\text { cover both QM and OM. The data set goes from } 1980 \text { to } \\
\text { 2017, which helps to visually illustrate Kaizen's three-decade } \\
\text { history. }\end{array}$ & $\begin{array}{l}\text { CI and Kaizen fueled a mid-1990s enthusiasm spike, following which } \\
\text { interest levels seemed to decrease. Thus, it seems that after } 2010 \text {, interest } \\
\text { in these areas skyrocketed. It was found that Kaizen is well known by } \\
\text { certain management members, but completely disregarded by others. } \\
\text { The results indicate that Kaizen's theoretical basis and connection to CI } \\
\text { need strengthening and clarification. }\end{array}$ \\
\hline 3 & $\begin{array}{l}\text { Garcia et al., (2018) } \\
{\left[{ }^{14]}\right.}\end{array}$ & $\begin{array}{l}\text { To direct academics who are researching } \\
\text { Kaizen philosophy to the best papers, the } \\
\text { most productive writers, and the most } \\
\text { important scientific publications related to } \\
\text { the subject }\end{array}$ & $\begin{array}{l}\text { To accomplish the goal, a descriptive bibliometric study was } \\
\text { conducted analyzing citations from } 138 \text { papers in Scopus } \\
\text { (Elsevier) from } 2006 \text { to 2016. A database to track each of the } \\
\text { bibliometric indicators' core variables was created for the } \\
\text { document search. }\end{array}$ & $\begin{array}{l}\text { Even though the number of articles published has fallen in both } 2014 \text { and } \\
2015 \text {, the citation data still indicates that scholarly interest has risen. The } \\
\text { papers on the Kaizen philosophy got the most citations in all of these } \\
\text { three disciplines. This seems to be the case for the Decision Sciences } \\
\text { category. }\end{array}$ \\
\hline 4 & $\begin{array}{l}\text { Al-Hyari } \\
(2019)^{[15]}\end{array}$ et $\quad$ al., & $\begin{array}{l}\text { To look at the outcomes of using the } \\
\text { Kaizen technique in a caravan repair } \\
\text { project in the Zaatari camp on the } \\
\text { Jordanian-Syrian border. }\end{array}$ & $\begin{array}{l}\text { This qualitative research employs an exploratory strategy. } \\
\text { The data was gathered through interviews and on-site } \\
\text { observations with project employees who were } \\
\text { knowledgeable about the maintenance project. Quality } \\
\text { control and causal effect links are discovered and explained } \\
\text { with the use of Kaizen diagramming (fishbone). }\end{array}$ & $\begin{array}{l}\text { According to the findings, the Kaizen technique was cost-effective in } \\
\text { both money and time. } \\
\text { Furthermore, waste reduction may be done with a number of tools and } \\
\text { readily combined with the Kaizen method. The Kaizen approach is a } \\
\text { reliable and efficient method for tackling all types of inefficiencies in the } \\
\text { caravan repair operation. }\end{array}$ \\
\hline 5 & $\begin{array}{l}\text { Garcia et al., (2009) } \\
{[16]}\end{array}$ & $\begin{array}{l}\text { To examine how Kaizen Events could } \\
\text { improve on-the-job efficiency. It takes } \\
\text { three to five days for teams to form and } \\
\text { then implement change. }\end{array}$ & $\begin{array}{l}\text { The empirical research will consist of a description of the } \\
\text { outcomes acquired at } 11 \text { automobile component } \\
\text { manufacturing companies. Over a } 9-12 \text {-month period, we } \\
\text { followed up on various initiatives in each organization. }\end{array}$ & $\begin{array}{l}\text { It should be emphasized that nearly all of the organizations have already } \\
\text { taken steps to improve their procedures, with a noticeable increase in } \\
\text { machine efficiency of approximately } 18 \% \text {. Decreased changeover time } \\
\text { benefits efficiency since extra machine production time can be obtained } \\
\text { if required. Instead of making more changes, the company can use the } \\
\text { fact that changeover is faster to make more of them. }\end{array}$ \\
\hline 6 & $\begin{array}{l}\text { J Singh and H Singh } \\
(2012)^{[17]}\end{array}$ & $\begin{array}{l}\text { To evaluate the literature and offer an } \\
\text { overall picture of continual progress }(\mathrm{CI}) \text {. } \\
\text { It is a survey of different } \mathrm{CI} \text { approaches } \\
\text { exhibited by various industrial companies } \\
\text { worldwide. }\end{array}$ & $\begin{array}{l}\text { The article summarises a wide range of CI approaches shown } \\
\text { by industrial companies worldwide. Additionally, potential } \\
\text { ramifications regarding CI techniques in industrial } \\
\text { companies have also been addressed. }\end{array}$ & $\begin{array}{l}\text { This article outlines the principles, case studies, and surveys related to } \\
\text { the CI technique. The benefits of CI programs for industrial performance } \\
\text { enhancement have also been noted. }\end{array}$ \\
\hline 7 & Chen Hua Chung & The goal of this study is to give a & The study's 6 philosophies are Traditional Values, Process- & The Kaizen Tire is a concept that reflects Kaizen's complete \\
\hline
\end{tabular}


International Journal of Engineering Applied Sciences and Technology, 2021

Vol. 6, Issue 2, ISSN No. 2455-2143, Pages 77-94

Published Online June 2021 in IJEAST (http://www.ijeast.com)

\begin{tabular}{|c|c|c|c|c|}
\hline & $(2018)^{[18]}$ & $\begin{array}{l}\text { comprehensive philosophical framework } \\
\text { for Kaizen. }\end{array}$ & $\begin{array}{l}\text { Oriented Philosophy, Edification, Perfection, and True } \\
\text { Mindfulness, Completeness, (and integrates). Furthermore, } \\
\text { the Power of One is a one-stop Kaizen shop. }\end{array}$ & $\begin{array}{l}\text { philosophical basis. It shows the broad picture as well as the } \\
\text { interconnectivity of the six Kaizen facilitation principles. It also suggests } \\
\text { that Kaizen may be utilized as a new philosophical approach for } \\
\text { integrating action and cognition. }\end{array}$ \\
\hline 8 & $\begin{array}{l}\text { J Singh and H Singh } \\
(2015)^{[19]}\end{array}$ & $\begin{array}{l}\text { To give an insight into the history and } \\
\text { current state of continuous improvement } \\
\text { research (CI). }\end{array}$ & $\begin{array}{l}\text { Classification of CI thus far has been extremely sparse. The } \\
\text { article summarizes different CI deployment methods shown } \\
\text { by diverse industrial companies worldwide. CI methods } \\
\text { presented by a variety of academics and practitioners are also } \\
\text { highlighted. }\end{array}$ & $\begin{array}{l}\text { This article offers an overview of CI, from its origins to the most } \\
\text { advanced methods employed in companies today. Classification of CI } \\
\text { thus far has been extremely sparse. The article summarizes different CI } \\
\text { deployment methods shown by diverse industrial companies worldwide. } \\
\text { CI methods presented by a variety of academics and practitioners are } \\
\text { also highlighted. }\end{array}$ \\
\hline 9 & Iwao (2018) ${ }^{[20]}$ & $\begin{array}{l}\text { To observe continuous improvement in a } \\
\text { particular plant over time and the variety } \\
\text { and actuality of kaizen in Toyota }\end{array}$ & $\begin{array}{l}\text { Research Kaizen innovations come in a variety of sizes, such } \\
\text { as the number of stakeholders, the amount of investment, and } \\
\text { the economic consequences. According to the research, } \\
\text { kaizen management necessitates organizational design in } \\
\text { order to have the most potential impact. Kaizen is supported } \\
\text { by Toyota work teams as well as product/process design } \\
\text { engineers. }\end{array}$ & $\begin{array}{l}\text { According to existing research, kaizen (continuous improvement) is a } \\
\text { collection of modest, discrete and continuous, incremental process } \\
\text { improvements implemented by workers/operators and their leaders. } \\
\text { According to research performed at one of Toyota Motor Company's } \\
\text { major facilities, the Takaoka plant, minor product design modifications } \\
\text { are occasionally required. }\end{array}$ \\
\hline 10 & Bond (1999) ${ }^{[21]}$ & $\begin{array}{l}\text { To evaluate the function of performance } \\
\text { measurement in the process of continuous } \\
\text { improvement. }\end{array}$ & $\begin{array}{l}\text { A kaizen continuous improvement programme may be used } \\
\text { to enhance a steady process. A significant step-change in } \\
\text { performance that radical re-engineering cannot accomplish } \\
\text { may be re-engineered by radical restructuring. According to } \\
\text { the research, each of these stages has distinct features. }\end{array}$ & $\begin{array}{l}\text { The report was based on an examination of both kaizen and radical } \\
\text { process re-engineering projects in a major multinational corporation. } \\
\text { The research has practical consequences for anyone who do the kind of } \\
\text { work that the University of Aberdeen does. It is said that the process life } \\
\text { cycle includes four distinct phases, each with its own set of features. }\end{array}$ \\
\hline
\end{tabular}




\section{International Journal of Engineering Applied Sciences and Technology, 2021 Vol. 6, Issue 2, ISSN No. 2455-2143, Pages 77-94 \\ Published Online June 2021 in IJEAST (http://www.ijeast.com)}

Kaizen is a management principle, a component of Total Quality Management, and a philosophy for continuous development. The research conducted by Gracia suggests that Kaizen's theoretical foundation and relationship to CI need to be strengthened and clarified. Despite a decrease in the number of papers published in 2014 and 2015, the data obtained reflect a growing interest in the scientific community in its study over the last decade. In Jordan's Zaatari Camp. The primary factor driving companies to embrace continuous improvement (CI) methods such as Kaizen is problem identification. The study will describe two of the most useful methods for detecting issues. The research will look at the "Zaatari Camp." The Norwegian Refugee Council (NRC) is a humanitarian organization that assists Jordanian refugees. The NRC's engineering section discovered that repairing caravans saves more money and time than replacing broken ones with new ones. Repairing a large number of caravans is regarded an innovative effort in Jordan, and it seems to be a construction project.

In Jordan, a caravan repair project has been performed using Kaizen as a CI approach. Interviews and on-site observations with staff involved in the caravan maintenance project were used to gather data. Site visits were conducted between September and December 2018 to collect data. Kaizen will continue to work on the caravan repair project's planning and implementation, as well as research findings based on process observation during implementation and interviews with employees who worked on the caravan maintenance project. Any operations that can be improved by Kaizen will be changed, and those changes will be checked using the PDCA cycle. Kaizen is a revolutionary approach to maintenance that focuses on improving quality and efficiency. The goal of the project was to make caravans more dependable, efficient, and easy to maintain. Validation, education, and integration are the three processes of repairing a caravan. Kaizen is a method of improving a project's caravan quality.

In his research, Chen Hua Chung (2018) ${ }^{[18]}$ proposed the Kaizen Wheel as a symbol of "perfection," which is the ultimate aim of Kaizen. According to Kiyoshi Matsumoto, the wheel indicates both a moving force and a "leading" role. He claims that the Kaizen concept necessitates "destroying" old habits, methods of conducting business, and thinking. According to Mitsumoto, Kaizen is more than simply a "CI"; it is a
"TCI," which stands for "constant renovation." The Kaizen Wheel was originally introduced during a seminar hosted by the Japanese Union of Researchers and Technologists in 1950. Many problem-solving ideas, notably Walter A. Shewart's "SpecificationProduction-Inspection" Cycle, were used to build W. Edward Deming's "scientific method." The Kaizen Wheel will make it easier to utilize the Deming Wheel, PDCA and PDSA Cycles, and other tools to increase their influence and advantages.

Review on Kaizen in Automotive industries:

Kaizen is a continuous improvement method that focuses on quality, technology, procedures, organizational values, profitability, protection, and mentorship. Rather than Toyota, the Toyota Way has been effectively implemented at numerous dealerships and businesses. Toyota Saudi Arabia's Port Installed Option Center (PIOC) follows the kaizen concepts. The PIOC's goal is to become the Toyota Network's top car accessory manufacturing line, using TPS and Toyota Way to meet market demands and achieve business success. In one of the research articles, the Kaizen goal was to adopt TPS in order to prevent the construction of new facilities and the hiring of more personnel. 
International Journal of Engineering Applied Sciences and Technology, 2021

Vol. 6, Issue 2, ISSN No. 2455-2143, Pages 77-94

Published Online June 2021 in IJEAST (http://www.ijeast.com)

Table 4: Summary of kaizen in automotive industries review

\begin{tabular}{|c|c|c|c|c|}
\hline Sl no & Authors & Purpose & Practical Approach & Key Research Findings \\
\hline 1 & $\begin{array}{l}\text { Vieiraa et al., (2012) } \\
\text { [22] }\end{array}$ & $\begin{array}{l}\text { A Kaizen-based approach is used to } \\
\text { optimize performance and enhance } \\
\text { working conditions in lean manufacturing } \\
\text { automotive systems. }\end{array}$ & $\begin{array}{l}\text { Questionnaires were used to explore whether a lean } \\
\text { production approach based on the Toyota production } \\
\text { system was used at a vehicle manufacturer in Paraná, } \\
\text { Brazil brought in any improvements }\end{array}$ & $\begin{array}{l}\text { Reduced work-life stress and financial savings are related to workplace } \\
\text { design. Most of the big car manufacturers are increasing their profits while } \\
\text { cutting manufacturing employment. Workers are eager to adopt the lean } \\
\text { method, initiative kaizen improves workplace and procedures } 82 \% \text { of } \\
\text { respondents favored harmonizing the system ergonomics with the existing } \\
\text { approach. }\end{array}$ \\
\hline 2 & $\begin{array}{l}\text { Abdulmouti } \quad \text { (2015) } \\
{[23]}\end{array}$ & $\begin{array}{l}\text { To present the results of implementing } \\
\text { Kaizen concepts at Toyota Saudi Arabia's } \\
\text { Port Installed Options Center. }\end{array}$ & $\begin{array}{l}\text { This study case analyzed the results of an implementation } \\
\text { of Kaizen as a case study }\end{array}$ & $\begin{array}{l}\text { Annual savings top } \$ 9 \text { million productions increased by } 13 \% \text { per year (from } \\
188000 \text { to } 212400 \text { automobiles). A Kanban system with just-in-time } \\
\text { production enabled inventory reduction. Quality was present in each step and } \\
\text { phase of the products, reducing vehicle damages. For Toyota, every problem } \\
\text { ended up being again, and they knew it. }\end{array}$ \\
\hline 3. & Dias et al., (2019) ${ }^{[24]}$ & $\begin{array}{l}\text { To optimize a production line, with the } \\
\text { main goal of increasing its production } \\
\text { capacity so that it could meet client } \\
\text { demands. }\end{array}$ & $\begin{array}{l}\text { Several continuous improvements and lean approaches, } \\
\text { including line balance, standard work, visual } \\
\text { management, and } 5 \mathrm{~S} \text {, were employed in the processes. }\end{array}$ & $\begin{array}{l}\text { The work that was done resulted in a } 37 \text { percent increase in production line } \\
\text { capacity and a } 22 \text { percent rise in the line's overall equipment effectiveness. }\end{array}$ \\
\hline 4. & Holtskog (2013) ${ }^{[25]}$ & $\begin{array}{l}\text { To trace the history of continuous } \\
\text { improvement in one of Norway's most } \\
\text { major automotive sector clusters, where it } \\
\text { has been a long-standing concern. }\end{array}$ & $\begin{array}{l}\text { At the company level, at the team or department level, } \\
\text { and a subjective level, a survey with } 603 \text { respondents } \\
\text { answering } 20 \text { questions was undertaken. }\end{array}$ & $\begin{array}{l}\text { More than } 600 \text { respondents believe that continuous improvement is a built-in } \\
\text { element of their daily work tasks. Also, disparities are depending on the job a } \\
\text { person performs in a company. These findings reveal that continuous } \\
\text { improvement is far from simple, and it has a cultural foundation that the Lean } \\
\text { tradition ignores. Workers' unions are critical to the success of manufacturing } \\
\text { floor changes. }\end{array}$ \\
\hline 5 & $\begin{array}{l}\text { Darmawan } \\
(2018)^{[26]}\end{array}$ et al., & $\begin{array}{l}\text { The goal of this study was to use the Kaizen } \\
\text { approach to lower the main defect rate in } \\
\text { the pasting process through eight PDCA } \\
\text { cycles. }\end{array}$ & $\begin{array}{l}\text { To help solve the problem, a descriptive exploratory } \\
\text { study was utilized. They employed a what-why analysis } \\
\text { to find the source of their issues. One of the reasons the } \\
\text { problem re-emerged after making modifications is that }\end{array}$ & $\begin{array}{l}\text { Using the eight PDCA Kaizen implementation, manufacturing process issues } \\
\text { may be found and removed. identifying the fault source (jamming plate). } \\
\text { Using Kaizen-based PDCA for steps } 8 \text {, PDCA to minimize in-line defects } \\
\text { results in a } 38 \% \text { reduction in plate scrap. This business will perform productive } \\
\text { maintenance on the pasting machine to keep it in good working order and } \\
\text { promote further development. }\end{array}$ \\
\hline 6 & $\begin{array}{l}\text { Fonesca and } \\
\text { Domingues (2018) }{ }^{[27]}\end{array}$ & $\begin{array}{l}\text { To determine the extent to which Kaizen } \\
\text { and other CI approaches are used within } \\
\text { Portuguese ISO 9001 certified firms, } \\
\text { namely those that have already } \\
\text { implemented ISO 9001:2015. }\end{array}$ & $\begin{array}{l}\text { A quantitative study was conducted using an online } \\
\text { survey. Of the } 309 \text { valid replies, } 71 \text { organizations were } \\
\text { previously certified to ISO } 9001: 2015 \text {, while } 238 \text { were } \\
\text { certified to ISO } 9001: 2008 \text {. Five managers in a focus } \\
\text { group carefully assessed the results of the statistical } \\
\text { study. }\end{array}$ & $\begin{array}{l}\text { The Portuguese ISO } 9001 \text { certified companies use Kaizen, Lean, and Six } \\
\text { Sigma (SS) approaches. The mean and median adoption rates of customer } \\
\text { enhancement strategies are higher than those in the industry that are still } \\
\text { accredited. The Kruskal-Wallis test, on the other hand, revealed no significant } \\
\text { differences. }\end{array}$ \\
\hline 7 & Prayuda (2020) ${ }^{[28]}$ & To explore the framework & This was a descriptive qualitative study. observation, & Kaizen-culture application boosts productivity and perceived benefits. Kaizen \\
\hline
\end{tabular}


International Journal of Engineering Applied Sciences and Technology, 2021

Vol. 6, Issue 2, ISSN No. 2455-2143, Pages 77-94

Published Online June 2021 in IJEAST (http://www.ijeast.com)

\begin{tabular}{|c|c|c|c|c|}
\hline & & $\begin{array}{l}\text { implementing a kaizen culture at PT AGP } \\
\text { company. }\end{array}$ & $\begin{array}{l}\text { interrogation, and documentary evidence Reduction, } \\
\text { presentation, and conclusion are used in this study. Using } \\
\text { Kaizen in employee enrichment. }\end{array}$ & $\begin{array}{l}\text { is being launched company-wide. Kaizen application will improve employees' } \\
\text { expectations of personal growth and company value. Every company-wide } \\
\text { Kaizen practice is employed by the corporation. Workplace culture develops } \\
\text { a kaizen work culture that is more receptive to company reforms. Employee } \\
\text { contributions improve quality, lower costs, and reduce delivery time. }\end{array}$ \\
\hline 8 & Pinto et al., (2019) [29] & $\begin{array}{l}\text { Works compile a case study on a } \\
\text { multinational corporation that was } \\
\text { responsible for manufacturing parts for the } \\
\text { automotive industry }\end{array}$ & $\begin{array}{l}\text { Compliance with the IATF 16949: } 2016 \text { standard and a } \\
\text { model were also created for the supervisors of spare } \\
\text { parts. These changes brought Lean tools into play to } \\
\text { improve procedures and information flows. }\end{array}$ & $\begin{array}{l}\text { Project was successfully performed, and performance measures were adopted, } \\
\text { with support data now being gathered and computed automatically on a regular } \\
\text { basis, and replacement parts organization was verified to minimize warehouse } \\
\text { space and maintain a low inventory level. To arrange the mold exchange } \\
\text { operations, the SMED approach was utilized, and the Lean } 5 \mathrm{~S} \text { tool was used. } \\
\text { The efficiency rate is considerably over } 90 \% \text {. }\end{array}$ \\
\hline 9 & $\begin{array}{l}\text { Charles and Chucks } \\
(2012)^{[30]}\end{array}$ & $\begin{array}{l}\text { To analyze the effect of functional and } \\
\text { organizational variables on workers' } \\
\text { involvement in Kaizen in the South African } \\
\text { automotive components industry }\end{array}$ & $\begin{array}{l}\text { This study is solely focused on South African businesses } \\
\text { that produce vehicles and components. The study will } \\
\text { assist assess Kaizen suggestion system workers' } \\
\text { productivity and success. This begins the future research } \\
\text { of vehicle participation and empowerment. empowered } \\
\text { and engaged workers }\end{array}$ & $\begin{array}{l}\text { In summary, the research has shown that the Kaizen proposal scheme is an } \\
\text { essential instrument for managing strategic goals in organizational } \\
\text { development. The research also encourages integrating employee suggestion } \\
\text { systems within the organization's process, as well as the importance of workers } \\
\text { learning how to use Kaizen suggestion tools. }\end{array}$ \\
\hline 10 & $\begin{array}{l}\text { Venkataiah and Sagi } \\
(2012)^{[31]}\end{array}$ & $\begin{array}{l}\text { To evaluate the effect of different Kaizen } \\
\text { Events and Determinants on long-term } \\
\text { growth. }\end{array}$ & $\begin{array}{l}\text { This research improves scholarly understanding of } \\
\text { Kaizen event sustainability. Additional discussion topics } \\
\text { exist for Kaizen implementation and perceived quality } \\
\text { performance in the chosen companies. }\end{array}$ & $\begin{array}{l}\text { Automobile manufacturing companies are acting as a vital component of the } \\
\text { growing economy by creating employment for both urban and rural } \\
\text { workforce. The study suggests Automobile manufacturing firms must increase } \\
\text { the implementation of kaizen events in Indian automobile companies. }\end{array}$ \\
\hline
\end{tabular}


Lean manufacturing, according to Vieiraa et al. (2012), is a new way of doing things in based on the production systems capable of delivering efficient operations and durability. Product quality, tardiness, and accidents are lower in businesses that use lean systems and the Kaizen technique than in organizations that do not use the same idea. Work environment is a scientific field that investigates how persons interact with other components of the system. A more ergonomic office design can boost productivity and job quality. Ergonomics aims to provide employees with the greatest working circumstances possible in order to prevent unintentional injury or excessive tiredness and to increase revenue.

After successfully implementing it, Raufoss Automobile is a Norwegian business that employ more people than ever before (Halvor Holtskog, 2013) ${ }^{[25]}$. The primary technique utilized was line balancing, which included levelling the weights across stations on the manufacturing line and thereby decreasing the line's cycle time. This effort improved line efficiency, reduced waste, and increased flexibility by creating continuous integration with three, four, and five workers. Five businesses were polled to find out how their workers felt about continuous improvement.
Leaders at all levels of the company were much more enthusiastic about the continuing improvement effort than the operators. White-collar employees, on the other hand, mistook it for a top-down strategy, which contradicts what Toyota officials have stated.

The goal of kaizen culture is "quality, cost, and delivery (quality, price, delivery) -QCD" The main concern of the company is the quality of its employees. The parent company monitors each work process and applies work standards. It was found that the company had suboptimal use of the idea of a verbal suggestion system by reporting to the direct supervisor. Kaizen's TQC / TQM is carried out by the quality section (Prayuda, 2020) ${ }^{[28]}$. The industrial sector has an important role in determining the competitiveness of nations in the world.

Review on Success Factor Implementation:

This section answers the last and final research question framed in the detail, by reviewing 5 published papers. The published papers were picked from the period 2015 onwards, to get the advanced information and understanding of this concept. 
International Journal of Engineering Applied Sciences and Technology, 2021

Vol. 6, Issue 2, ISSN No. 2455-2143, Pages 77-94

Published Online June 2021 in IJEAST (http://www.ijeast.com)

Table 5: Implementation of Success Factors Summary

\begin{tabular}{|c|c|c|c|c|}
\hline Sl no & Authors & Purpose & Practical Approach & Key Research Findings \\
\hline 1 & Janjic et al., (2019) ${ }^{[32]}$ & $\begin{array}{l}\text { To outline the major success criteria } \\
\text { for kaizen implementation, as well as } \\
\text { the major advantages of its use, in } \\
\text { businesses in emerging countries. }\end{array}$ & $\begin{array}{l}\text { The study employs factor analysis. A } \\
\text { questionnaire was then designed based on the } \\
\text { objectives and methodology of data } \\
\text { collection. The collected data was analyzed } \\
\text { and conclusions were made. }\end{array}$ & $\begin{array}{l}\text { Critical success factors were found to be initiating and } \\
\text { reviewing alterations, systems, employee support, } \\
\text { establishing an appropriate assessment method, and } \\
\text { creating an internal communication system. improved } \\
\text { company performance is the most significant economic } \\
\text { advantage of kaizen implementation. }\end{array}$ \\
\hline 2 & $\begin{array}{l}\text { Omotayo et al., (2018) } \\
\text { [33] }\end{array}$ & $\begin{array}{l}\text { To identify key performance indicators } \\
\text { in lean system construction } \\
\text { implemented kaizen Nigeria. Also, to } \\
\text { maintain stakeholders' relationships } \\
\text { and business management and profit } \\
\text { are key, as with all construction firms. }\end{array}$ & $\begin{array}{l}\text { Exploratory factor analysis statistical tests } \\
\text { classified the critical factors outlined in the } \\
\text { research survey. }\end{array}$ & $\begin{array}{l}\text { The exploratory factor analysis tests showed that } \\
\text { construction management function (CMF), operational } \\
\text { efficiency (OE), construction business ethics (CBE), and } \\
\text { construction cost management were the key success } \\
\text { variables (CCM). With opinions on the quality measures } \\
\text { that drive kaizen, kaizen may be applied in Nigerian } \\
\text { construction companies. This research backs up the use } \\
\text { of kaizen initiatives for cost and time savings. }\end{array}$ \\
\hline 3 & Hailu et al., (2017) ${ }^{[34]}$ & $\begin{array}{l}\text { To discover crucial success elements } \\
\text { and design and implement sustained } \\
\text { kaizen practices }\end{array}$ & $\begin{array}{l}\text { The study utilized numerous materials and } \\
\text { procedures. } 20 \text { outcomes, theoretical models, } \\
\text { and } 10 \text { hypotheses are employed in the } \\
\text { research. Regression is applied to the data } \\
\text { gathered }\end{array}$ & $\begin{array}{l}\text { This experiment proved that the eight critical parameters } \\
\text { affect success indicators. They are: education and } \\
\text { training are referred to as Manufacturing process control } \\
\text { is related to personnel performance and production costs. } \\
\text { Effective communication is dependent on planning. } \\
\text { Therefore, the Ethiopian researcher developed a model } \\
\text { for long-term Kaizen in the shoe industry. }\end{array}$ \\
\hline 4 & $\begin{array}{l}\text { Maroof and Mahumud } \\
\text { (2015) }{ }^{[35]}\end{array}$ & $\begin{array}{l}\text { To examines some of the elements that } \\
\text { contribute to the effective } \\
\text { implementation of Kaizen in small and } \\
\text { medium businesses, as well as the } \\
\text { problems they face. }\end{array}$ & $\begin{array}{l}\text { The study conducts a systematic literature } \\
\text { review to briefly understand the } \\
\text { implementation factors. }\end{array}$ & $\begin{array}{l}\text { Kaizen implementation has been linked to the presence } \\
\text { of a Kaizen champion, good information management, } \\
\text { and employee empowerment. Change resistance, } \\
\text { engagement difficulties, lack of understanding of the } \\
\text { company's strategic plan, and inability to handle } \\
\text { continuous improvement were some of the Kaizen } \\
\text { adoption challenges identified in the study. }\end{array}$ \\
\hline
\end{tabular}


International Journal of Engineering Applied Sciences and Technology, 2021

Vol. 6, Issue 2, ISSN No. 2455-2143, Pages 77-94

Published Online June 2021 in IJEAST (http://www.ijeast.com)

\begin{tabular}{|c|c|c|c|c|}
\hline 5 & Aleu et al., (2018) ${ }^{[36]}$ & $\begin{array}{l}\text { To locate the Critical Success Factors } \\
\text { (CSFs) that are closely linked to CIP } \\
\text { success in hospitals }\end{array}$ & $\begin{array}{l}\text { Any CIP leaders/facilitators from hospitals } \\
\text { that performed at least one CIP in the } \\
\text { previous two years were surveyed } \\
\text { retrospectively. }\end{array}$ & $\begin{array}{l}\text { The } 116 \text { responses generated three primary conclusions. } \\
47 \text { out of } 53 \text { CSFs were rated as critically significant in } \\
\text { hospitals' CIP performance ( } 4 \text { or higher on a six-point } \\
\text { scale). Moreover, the CSFs used in this study and other } \\
\text { studies to achieve CIP effectiveness differ. Lastly, the } \\
\text { type of CIP impacts } 16 \text { of the } 53 \text { CSFs for hospital CIP } \\
\text { success. }\end{array}$ \\
\hline 6 & García et 1., (2012) ${ }^{[37]}$ & $\begin{array}{l}\text { The goal of this study is to discover } \\
\text { certain dependencies between } \\
\text { necessary actions linked to human } \\
\text { factors in the kaizen implementation } \\
\text { process and the benefits received, } \\
\text { demonstrating the impact of variables. }\end{array}$ & $\begin{array}{l}\text { A literature review was conducted initially to } \\
\text { identify components, through which } \\
\text { quantitative analysis was conducted on the } \\
\text { data obtained from it. }\end{array}$ & $\begin{array}{l}\text { Education, commitment, and motivation are all critical } \\
\text { for kaizen project communication. Employee motivation } \\
\text { in a kaizen implementation process requires management } \\
\text { commitment. For workers to be satisfied, communication } \\
\text { and motivation are essential. Worker satisfaction and } \\
\text { clear communication are critical to success in kaizen } \\
\text { implementation. Without worker satisfaction and } \\
\text { efficiency, clients will not have a great experience. }\end{array}$ \\
\hline 7 & Glover et al., (2011) ${ }^{[38]}$ & $\begin{array}{l}\text { To determine the factors that have the } \\
\text { most impact on employee attitudes and } \\
\text { commitment to Kaizen activities in the } \\
\text { workplace. }\end{array}$ & $\begin{array}{l}\text { The construct validity of all multi-item } \\
\text { survey measures was investigated using } \\
\text { exploratory factor analysis (EFA). }\end{array}$ & $\begin{array}{l}\text { Adapting adjustments was revealed to be the most } \\
\text { powerful predictor of work area enthusiasm and } \\
\text { engagement. The performance appraisal was also proven } \\
\text { to be a good, predictive factor of Kaizen attitudes. The } \\
\text { discovery about production system modifications is } \\
\text { consistent with prior studies in this area. }\end{array}$ \\
\hline 8 & Farris et al (2009) ${ }^{[39]}$ & $\begin{array}{l}\text { To discover the collection of input and } \\
\text { process variables that contribute to } \\
\text { employee attitudes and problem- } \\
\text { solving skills in Kaizen events }\end{array}$ & $\begin{array}{l}\text { Organizational kaizen events are focused on } \\
\text { work area change and staff development. } \\
\text { Anecdotal design recommendations abound, } \\
\text { but there is little scientific data to back up the } \\
\text { findings. }\end{array}$ & $\begin{array}{l}\text { This research has assessed the impact of input and } \\
\text { process variables on human resource outcomes for } 51 \\
\text { company events. More attention has been shown in } \\
\text { kaizen events since the } 1990 \text { s, but more research has still } \\
\text { to be done. The operations management and industrial } \\
\text { engineering research community must help businesses } \\
\text { discover and comprehend this phenomenon. }\end{array}$ \\
\hline
\end{tabular}


International Journal of Engineering Applied Sciences and Technology, 2021

Vol. 6, Issue 2, ISSN No. 2455-2143, Pages 77-94

Published Online June 2021 in IJEAST (http://www.ijeast.com)

\begin{tabular}{|c|c|c|c|c|}
\hline 9 & Mojica et al., (2014) ${ }^{[40]}$ & $\begin{array}{l}\text { To determine the most crucial criteria } \\
\text { that will assure Kaizen's benefits. }\end{array}$ & $\begin{array}{l}\text { The goal of Confirmatory Factor Analysis } \\
\text { was to validate the links between variables } \\
\text { and factors. }\end{array}$ & $\begin{array}{l}\text { The paper stated that management commitment and } \\
\text { customer attitude are the most essential aspects in } \\
\text { ensuring the Kaizen benefits. }\end{array}$ \\
\hline 10 & Vento et al., (2016) ${ }^{[41]}$ & $\begin{array}{l}\text { The purpose of this paper is to examine } \\
\text { how managerial commitment and } \\
\text { human resource professional } \\
\text { development impact Kaizen } \\
\text { implementation in Mexican } \\
\text { maquiladora } \text { manufacturing } \\
\text { companies. }\end{array}$ & $\begin{array}{l}423 \text { business enterprises from Tabasco, Baja } \\
\text { California, Sinaloa, and Chihuahua utilize a } \\
\text { questionnaire in the process. } 4 \text { latent } \\
\text { variables: two that reflect management } \\
\text { commitment and human resource } \\
\text { professional development, and two that } \\
\text { pertain to benefits. }\end{array}$ & $\begin{array}{l}\text { It was found that managerial commitment leads to better } \\
\text { economic and human resource outcomes. the study's } \\
\text { primary contribution is the study's determination of } \\
\text { dependency measures }\end{array}$ \\
\hline
\end{tabular}




\section{International Journal of Engineering Applied Sciences and Technology, 2021 Vol. 6, Issue 2, ISSN No. 2455-2143, Pages 77-94 \\ Published Online June 2021 in IJEAST (http://www.ijeast.com)}

To conduct factor analysis, Janji et al. (2019) ${ }^{[32]}$ employed a questionnaire to collect data from Serbian manufacturing industries. The study discovered that the results of its use fell significantly short of expectations. Keep in mind that engineers are a critical component of a company's success or failure. They argue that emphasizing the involvement of engineers in this process is critical. Engineers connect top management, economics, the complex implementation team, and the workforce.

It is believed that instead of a rigid hierarchy, engineers should aim to build partnerships with workers. The study has a few problems, including limited sample size and the subjectivity of the responders. Its goal is to investigate the feasibility of implementing a CSF for kaizen as a transferable panacea in developing economies' construction industry. Kaizen is a method used by construction companies to estimate the cost of building materials and services while they are being built. Kaizen necessitates a high level of communication and collaboration, as well as a less bureaucratic management style.

To varying degrees, the Peacock shoe manufacturing industry has improved critical success factors. Political stability, contract and QS choices, and supplier material pricing were also mentioned in the report. The research examined $53 \mathrm{CSF}$ for CIPs, including Lean-Kaizen and Lean Six Sigma projects. Between research papers and this analysis, the researchers discovered significant changes in the role of CSFs in achieving CIP success. The findings are useful for CIP leaders and facilitators in hospitals, but it's also crucial to evaluate some research limitations and how they were resolved to improve research quality are the results founded by Gonzalez-Aleut al., $2018^{[36]}$.

Most authors emphasized the importance of good communication channels, as well as training and education, as these two aspects contributed to the successful adoption of CI in the industries. The majority of the ten studies examined focused on change, employee and team readiness, and commitment to change, while one author proposed a novel approach to change by incorporating change management systems.

\section{CONCLUSION AND DISCUSSION}

JIT (just in time) is a Japanese management approach that has been adopted in many Japanese manufacturing companies since the early 1970s. To respond to customer requests with minimal delays, Taiichi Ohno pioneered and perfected it inside Toyota's production operations. Just in Time inventory management is a type of inventory management in which goods are only received from suppliers when they are required. During the 1950s, Japan concentrated on improving performance by reducing the amount of money and space available. Eiji Toyota, the Chairman of Toyota, issued a direction to his employees to "eliminate the waste," laying the framework for JIT improvements.

Kaizen is systematic management using change management tools unique that focus on continual performance improvement. $\mathrm{CI}$ is a continuous improvement culture that aims to eliminate waste across an organization's systems and activities. It comprises everyone cooperating to grow without needing to invest a lot of money. The most wellknown of them are Lean Manufacturing, Six Sigma, and Lean Six Sigma. The outcomes of proven improvements can be implemented across the board.

A systematic literature review (SLR) is a form of study that attempts to address a specific research question. The primary goal of this SLR is to examine the literature on JIT Continuous Improvement. As indicated in Figure 1, research is divided into seven stages. The articles are organized into two categories: continuous improvement in the automobile sector and effective implementation factors for continuous improvement. Papers that focus on other features of JIT, on the other hand, are left out of the analysis. A total of "19" previously published publications are picked from the internet and retrieved. A thorough investigation of continuous improvement and $\mathrm{CI}$ in the automobile industry was carried out to determine the success factors for their deployment. This section presents an overview of CI, as well as its evolution and major implementation characteristics. According to the findings, Kaizen can be transferred to countries with cultures other than Japan's. Kaizen is a management concept that is a part of Total Quality Management.

The major drive driving firms to use continuous improvement (CI) methods like Kaizen is the identification of problems. A caravan repair project 


\section{International Journal of Engineering Applied Sciences and Technology, 2021 Vol. 6, Issue 2, ISSN No. 2455-2143, Pages 77-94 \\ Published Online June 2021 in IJEAST (http://www.ijeast.com)}

was completed in Jordan utilizing Kaizen as a CI approach. The idea was to improve the dependability and efficiency of caravans. Kaizen is a method of improving quality, technology, procedures, business culture, productivity, safety, and leadership through time. Instead of Toyota, the Toyota Way has been effectively implemented in many dealerships and businesses. Raufoss Automotive is a Norwegian firm with more employees than it has ever had, after the successful implementation of CI (Halvor Holtskog, 2013).

After conducting a thorough literature survey, it was evident that most authors pointed out the necessity of excellent communication channels, training, and education for successful CI adoption in the industries All the researchers investigated change, employee and team preparation, and commitment to change. One study advocated innovatively using change management tools. Future studies can adopt a quantitative analysis like Pareto to identify the vital few critical owing to the successful implementation of CI.

\section{REFERENCES}

[1] Lea, R., \& Parker, B. (1989). The JIT spiral of continuous improvement. Industrial Management \& Data Systems.

[2] Berling, C. (2000). Continuous improvement as seen from groups and'improvement agents'. Total Quality Management, 11(4-6), 484-489.

[3] Bessant, J. (1994). Towards total integrated manufacturing. International Journal of Production Economics, 34(3), 237-251.

[4] Audretsch, D. B., Martínez-Fuentes, C., \& Pardodel-Val, M. (2011). Incremental innovation in services through continuous improvement. The Service Industries Journal, 31(12), 1921-1930.

[5] Hayes, R. H. (1981). Why Japanese Factories Work. Harvard Business Review. July-August.

[6] Grönroos, C. (2007). Service management and marketing: customer management in service competition. John Wiley \& Sons.

[7] Bhuiyan, N., \& Baghel, A. (2005). An overview of continuous improvement: from the past to the present. Management decision.

[8] Dewey, A., \& Drahota, A. (2016). Introduction to systematic reviews: online learning module Cochrane Training. Retrieved from.

[9] Patino, C. M., \& Ferreira, J. C. (2018). Inclusion and exclusion criteria in research studies: definitions and why they matter. Jornal Brasileiro de Pneumologia, 44, 84-84.
[10] Mendiratta, V., Jain, A., Chander, R., Khan, A., \& Barara, M. (2011). A nine-year clinicoepidemiological study of Histoid Hansen in India. The Journal of Infection in Developing Countries, 5(02), 128-131.

[11] Aoki, K. (2008). Transferring Japanese kaizen activities to overseas plants in China. International Journal of Operations \& Production Management. [12] Carnerud, D., Jaca, C., \& Bäckström, I. (2018). Kaizen and continuous improvement-trends and patterns over 30 years. The TQM Journal.

[13] Suárez-Barraza, M. F., Ramis-Pujol, J., \& Kerbache, L. (2011). Thoughts on kaizen and its evolution: Three different perspectives and guiding principles. International Journal of Lean Six Sigma.

[14] Álvarez-García, J., Durán-Sánchez, A., \& del Río, M. D. L. C. (2018). Systematic bibliometric analysis on Kaizen in scientific journals. The TQM Journal.

[15] Al-Hyari, K. A., Zaid, M. K. A., Arabeyyat, O. S., Al-Qwasmeh, L., \& Haffar, M. (2019). The applications of Kaizen methods in project settings: applied study in Jordan. The TQM Journal.

[16] Marin-Garcia, J. A., Garcia-Sabater, J. J., \& Bonavia, T. (2009). The impact of Kaizen Events on improving the performance of automotive components' first-tier suppliers. International Journal of Automotive Technology and Management, 9(4), 362-376.

[17] Singh, J., \& Singh, H. (2012). Continuous improvement approach: state-of-art review and future implications. International Journal of Lean Six Sigma. [18] Chung, C. H. (2018). The Kaizen Wheel-an integrated philosophical foundation for total continuous improvement. The TQM Journal.

[19] Singh, J., \& Singh, H. (2015). Continuous improvement philosophy-literature review and directions. Benchmarking: An International Journal.

[20] Iwao, S. (2018). The Diversity and Reality of Kaizen in Toyota. In Industrial Competitiveness and Design Evolution (pp. 271-298). Springer, Tokyo.

[21] Bond, T. C. (1999). The role of performance measurement in continuous improvement. International Journal of Operations \& Production Management.

[22] Vieira, A. W., Nascimento, E. R., Oliveira, G. L., Liu, Z., \& Campos, M. F. (2012, September). Stop: Space-time occupancy patterns for $3 \mathrm{~d}$ action recognition from depth map sequences. In Iberoamerican congress on pattern recognition (pp. 252-259). Springer, Berlin, Heidelberg.

[23] Abdulmouti, H. (2015, March). The role of Kaizen (continuous improvement) in improving companies' performance: A case study. In 2015 


\section{International Journal of Engineering Applied Sciences and Technology, 2021 Vol. 6, Issue 2, ISSN No. 2455-2143, Pages 77-94 \\ Published Online June 2021 in IJEAST (http://www.ijeast.com)}

International Conference on Industrial Engineering and Operations Management (IEOM) (pp. 1-6). IEEE. [24] Dias, P., Silva, F. J. G., Campilho, R. D. S. G., Ferreira, L. P., \& Santos, T. (2019). Analysis and improvement of an assembly line in the automotive industry. Procedia Manufacturing, 38, 1444-1452.

[25] Holtskog, H. (2013). Continuous improvement beyond the lean understanding. Procedia Cirp, 7, 575579.

[26] Darmawan, H., Hasibuan, S., \& Purba, H. H. (2018). Application of Kaizen concept with 8 Steps PDCA to reduce in line defect at pasting process: A case study in automotive battery. Int. J. Adv. Sci. Res. Eng, 4(8), 97-107.

[27] Fonseca, L. M., \& Domingues, J. P. (2018). The best of both worlds? Use of Kaizen and other continuous improvement methodologies within Portuguese ISO 9001 certified organizations. The TQM Journal.

[28] Prayuda, R. Z. (2020). Continuous Improvement Through Kaizen In An Automotive Industry. Journal of Industrial Engineering \& Management Research, 1(1), 37-42.

[29] Fazeres-Ferradosa, T., Rosa-Santos, P., TaveiraPinto, F., Vanem, E., Carvalho, H., \& Correia, J. (2019, December). Advanced research on offshore structures and foundation design: part 1 . In Proceedings of the Institution of Civil EngineersMaritime Engineering (Vol. 172, No. 4, pp. 118-123). Thomas Telford Ltd.

[30] Charles, A. A., \& Chucks, O. K. (2012). Adopting the Kaizen suggestion system in South African Lean automotive components companies. Science Journal of Business Management, 2012.

[31] Venkataiah, D., \& Sagi, D. (2012). Relationship between kaizen events and perceived quality performance in Indian automobile industry.

[32] Janjic, M. M., Prévide, R. M., Fletcher, P. A., Sherman, A., Smiljanic, K., Abebe, D., ... \& Stojilkovic, S. S. (2019). Divergent expression patterns of pituitary gonadotropin subunit and $\mathrm{GnRH}$ receptor genes to continuous $\mathrm{GnRH}$ in vitro and in vivo. Scientific reports, 9(1), 1-14.

[33] Omotayo, F. O., \& OMOTOPE, A. R. (2018). Determinants of continuance intention to use online shops in Nigeria. Journal of Internet Banking and Commerce, 23(2), 1-48.

[34] Hailu, H., Kedir, A., Bassa, G., \& Jilcha, K. (2017). Critical success factors model developing for sustainable Kaizen implementation in manufactur-ing industry in Ethiopia. Management Science Letters, 7(12), 585-600.

[35] Maarof, M. G., \& Mahmud, F. (2016). A review of contributing factors and challenges in implementing kaizen in small and medium enterprises. Procedia economics and Finance, 35, 522-531.

[36] Gonzalez-Aleu, F., Van Aken, E. M., Cross, J., \& Glover, W. J. (2018). Continuous improvement project within Kaizen: critical success factors in hospitals. The TQM Journal.

[37] García, J. L., Maldonado, A. A., Alvarado, A., \& Rivera, D. G. (2014). Human critical success factors for kaizen and its impacts on industrial performance. The International Journal of Advanced Manufacturing Technology, 70(9-12), 2187-2198.

[38] Glover, W. J., Farris, J. A., Van Aken, E. M., \& Doolen, T. L. (2011). Critical success factors for the sustainability of Kaizen event human resource outcomes: An empirical study. International Journal of Production Economics, 132(2), 197-213.

[39] Farris, J. A., Van Aken, E. M., Doolen, T. L., \& Worley, J. (2009). Critical success factors for human resource outcomes in Kaizen events: An empirical study. International Journal of Production Economics, 117(1), 42-65

[40] Rivera-Mojica, D., \& Rivera-Mojica, L. (2014). Critical success factors for kaizen implementation. In Lean manufacturing in the developing world (pp. 157-178). Springer, Cham.

[41] Vento, M. O., Alcaraz, J. L. G., Macías, A. A. M., \& Loya, V. M. (2016). The impact of managerial commitment and Kaizen benefits on companies. Journal of Manufacturing Technology Management. 